\title{
Home range, habitat use, and migrations of hawksbill turtles tracked from Dry Tortugas National Park, Florida, USA
}

\author{
Kristen M. Hart ${ }^{1, *}$, Autumn R. Sartain ${ }^{2}$, Ikuko Fujisaki ${ }^{3}$, Harold L. Pratt Jr. ${ }^{4}$, \\ Danielle Morley ${ }^{5}$, Michael W. Feeley ${ }^{6}$
}

\author{
${ }^{1}$ U.S. Geological Survey, Southeast Ecological Science Center, Davie, Florida 33314, USA \\ ${ }^{2}$ Jacobs Technology, contracted to U.S. Geological Survey, Southeast Ecological Science Center, Davie, Florida 33314, USA \\ ${ }^{3}$ University of Florida, Ft. Lauderdale Research and Education Center, Davie, Florida 33314, USA \\ ${ }^{4}$ Center for Shark Research, Mote Tropical Marine Laboratory, 24244 Overseas Highway, Summerland Key, Florida 33042, USA \\ ${ }^{5}$ Florida Fish and Wildlife Conservation Commission, Marathon, Florida 33050, USA \\ ${ }^{6}$ National Park Service, South Florida Caribbean Network, Palmetto Bay, Florida 33157, USA
}

\begin{abstract}
To determine habitat-use patterns of sub-adult hawksbills Eretmochelys imbricata, we conducted satellite- and acoustic-tracking of 3 turtles captured in August 2008 within Dry Tortugas National Park (DRTO), south Florida, USA, in the Gulf of Mexico; turtles ranged in size from 51.9 to $69.8 \mathrm{~cm}$ straight carapace length. After 263,699, and $655 \mathrm{~d}$ of residence in the park, turtles migrated out of the DRTO. Within the park, core-use areas (i.e. $50 \%$ kernel density estimates) were 9.2 to $21.5 \mathrm{~km}^{2}$; all 3 turtle core-use areas overlapped in an area $6.1 \mathrm{~km}^{2}$ within a zone of the park with multiple human uses (e.g. fishing, anchoring). Two turtles migrated to Cuba and ceased transmitting after 320 and 687 tracking days; the third turtle migrated toward Key West, Florida, and ceased transmitting after 884 tracking days. The present study highlights previously unknown regional connections for hawksbills, possible turtle-harvest incidents, and fine-scale habitat use of sub-adult hawksbills within a United States National Park.
\end{abstract}

KEY WORDS: Hawksbill - Satellite - Acoustic $\cdot$ Telemetry $\cdot$ Kernel density estimate Harvest · Dry Tortugas

Resale or republication not permitted without written consent of the publisher

\section{INTRODUCTION}

Understanding home ranges and migration paths for wide-ranging marine species is critical for the design of effective conservation strategies targeting vulnerable life stages of imperiled taxa (Meylan 1999, Bowen et al. 2007, Benson et al. 2011). The hawksbill turtle Eretmochelys imbricata is a circumtropically distributed marine species that occupies coral reef habitats throughout most of its range (Carr et al. 1966, Mortimer \& Donnelly 2008), except in parts of the eastern Pacific where Gaos et al. (2012) recently discovered hawksbills living in mangrove estuaries. Generally considered spongivores (Meylan 1988, Van Dam \& Diez 1997), hawksbills also con- sume other species such as corallimorphs, hydroids, sea urchins and jellyfish (Carr et al. 1966, Leon \& Bjorndal 2002, Blumenthal et al. 2009b). In the Caribbean, hawksbills nest on both insular and mainland sandy beaches (Carr et al. 1966), often in areas with at least some vegetation (Kamel \& Mrosovsky 2005).

Like other species of marine turtles, hawksbill hatchlings enter into an initial pelagic phase, where they are likely taken up by strong ocean currents and transported to foraging grounds (Blumenthal et al. 2009a). These foraging grounds can be home to juveniles from many different nesting aggregations, each consisting of genetically distinct subpopulations (Bass et al. 1996, Velez-Zuazo et al. 2008). Long-term 
observations of resident juveniles at foraging grounds (e.g. Puerto Rico; Van Dam \& Diez 1997, 1998a) and close proximity of suitable nesting habitat to coral reefs where hawksbills were sighted stimulated debate about whether hawksbills had the need to migrate (see Meylan 1999). However, recaptures of tagged individuals away from original tagging locations (Parmenter 1983), genetic analysis of mixed stocks of hawksbills at foraging grounds (Bowen et al. 1996, 2007, Bass 1999), and satellite tracking studies conducted throughout the Caribbean over the last several decades have demonstrated that hawksbills are indeed migratory (Horrocks et al. 2001, Troëng et al. 2005, Van Dam et al. 2008). Previous records showed travel distances of 110 to $1936 \mathrm{~km}$ for adults and 46 to $900 \mathrm{~km}$ for juveniles (Meylan 1999). Longdistance migrations have been reported in other areas as well, with 2 tagged juveniles from the Seychelles resighted years later as a sub-adult and adult 1150 and $900 \mathrm{~km}$ away, respectively, from their original tagging locations (Mortimer et al. 2012).

The hawksbill was listed as critically endangered on the IUCN Red List of Threatened Species in 1996, based on an overall decline in the species of $>80 \%$, and extensive subpopulation declines in all ocean basins. Declines were due to over-harvesting, incidental take and degradation of habitat over the last 3 hawksbill generations (105 yr; Meylan \& Donnelly 1999, Mortimer \& Donnelly 2008). Wallace et al. (2010) recently defined 13 population segments or regional management units (RMUs) for hawksbills; however, they define 7 population segments as 'putative' RMUs because of a lack of information on distribution and genetics. DRTO hawksbills fall under the 'Atlantic, western Caribbean (USA)' RMU. This new RMU framework provides a strategy for organizing marine turtles into units of protection above the level of nesting populations, but below the level of species, within regional entities that might be on independent evolutionary trajectories.

According to the United States Endangered Species Act, hawksbills are endangered in all parts of their range (NMFS \& USFWS 1993, 1998). Because marine turtles undertake extensive migrations, reducing local populations can affect populations throughout the region (Bowen et al. 1996, 2007, Bass 1999, Eckert 2002). Effective implementation of management programs for hawksbills will require a thorough understanding of individual movements throughout the region and the spatial extent of home ranges and core-use areas they establish within foraging grounds.

Many approaches have been taken to understand hawksbill movements, including mark-recapture and flipper-tagging (Bjorndal et al. 1985, Leon \& Diez 1999, Richardson et al. 1999, Velez-Zuazo et al. 2008). Acoustic telemetry has also been used to elucidate horizontal movements of hawksbills and sometimes estimate home ranges, either actively with handheld receivers (Van Dam \& Diez 1998a, Witt et al. 2010, Scales et al. 2011), passively with fixed receiver arrays (Okuyama et al. 2005), or both (Blumenthal et al. 2009c). While passive acoustic telemetry is inherently limited by the number of receivers in a given array, it is less labor-intensive, provides a larger sample size, and can detect multiple individuals simultaneously and continuously throughout an array (Voegeli et al. 2001, Heupel et al. 2006, Scales et al. 2011). Within an array, acoustic telemetry data are useful for interpreting foraging area habitat use at a scale from 10 s to 100 s of meters and for discovering diel patterns of movement (Arendt et al. 2001, Heupel et al. 2006). To obtain home-range estimates beyond the scope of receiver arrays, however, satellite telemetry has emerged as the preferred tool and has been utilized to track many marine species in recent years (Hart \& Hyrenbach 2009), including sea turtles (Godley et al. 2008). Satellite telemetry can provide the data necessary for accurately estimating home ranges, as well as tracking individuals over large areas. Despite the increasing number of satellite telemetry studies focused on hawksbills, only a few studies have previously assessed home range size or core-use areas.

No home-range estimates for any size-class of hawksbills is available within United States continental waters. Additionally, no hawksbill homerange studies have focused primarily on the subadult size-class. Here, we investigate the foraging home range and migrations of 3 sub-adult hawksbills captured and tagged in Dry Tortugas National Park (DRTO), South Florida, USA. Using finer scale location accuracy provided by acoustic tracking in conjunction with satellite-tracking data, we aimed to determine both broad- and fine-scale habitat-use patterns of sub-adult hawksbills at this site. We also aimed to decipher diel movement patterns of 2 of the 3 satellite-tagged hawksbills. Understanding the home-range estimates, core-use areas and movement patterns of hawksbills within the park will help resource managers establish effective local management practices to protect this critically endangered species. Further, protecting this species at 1 foraging ground and furthering the understanding of its migration patterns will contribute to the conservation of hawksbills throughout the greater Caribbean region. 


\section{MATERIALS AND METHODS}

\section{Study site}

The Dry Tortugas consists of 7 small islands $\sim 100 \mathrm{~km}$

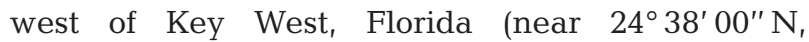
$82^{\circ} 55^{\prime} 12^{\prime \prime} W_{;}$Fig. 1). The area resembles an atoll, consisting of a series of carbonate banks and sand shoals in which the banks roughly form a circular pattern (Mallinson et al. 2003). The largest of the islands is Loggerhead Key $(\sim 1.5 \mathrm{~km}$ long $\times \sim 250 \mathrm{~m}$ wide). In 1908 the region was designated as a Wildlife Refuge, in 1935 a National Monument and in 1992 a National Park. More recently, in 2007, $120 \mathrm{~km}^{2}$ of the $\sim 262 \mathrm{~km}^{2}$ park was designated a research natural area (RNA), creating a no-take preserve within the park to foster ecological self-renewal by minimizing anthropogenic influences (National Park Service 2006). The creation of the DRTO RNA is part of a region-wide effort to strengthen marine protection and complement nearby reserves such as the North and South Tortugas Ecological Reserves (TNER, TSER) of the Florida Keys National Marine Sanctuary (FKNMS), established by the National Oceanic and Atmospheric Administration (NOAA) and the State of Florida. The sandy beaches of DRTO are monitored as part of the State of Florida's marine turtle nest monitoring program (see Witherington et al. 2009).

\section{Turtle capture and standard handling}

We captured hawksbill turtles Eretmochelys imbricata at DRTO in August 2008 by dip netting during the day ( $3 \mathrm{~m}$ handle with $84 \times 102 \mathrm{~cm}$ net) while aboard a $4.3 \mathrm{~m}$ Livingston skiff equipped with a $25 \mathrm{hp}$ motor. All procedures for turtle handling and sampling followed established protocols (NMFS SEFSC 2008). We tagged each animal with a passive integrated transponder (PIT) tag in the right shoulder region and affixed an individually numbered flipper tag to each of the rear flippers. Immediately after tag-

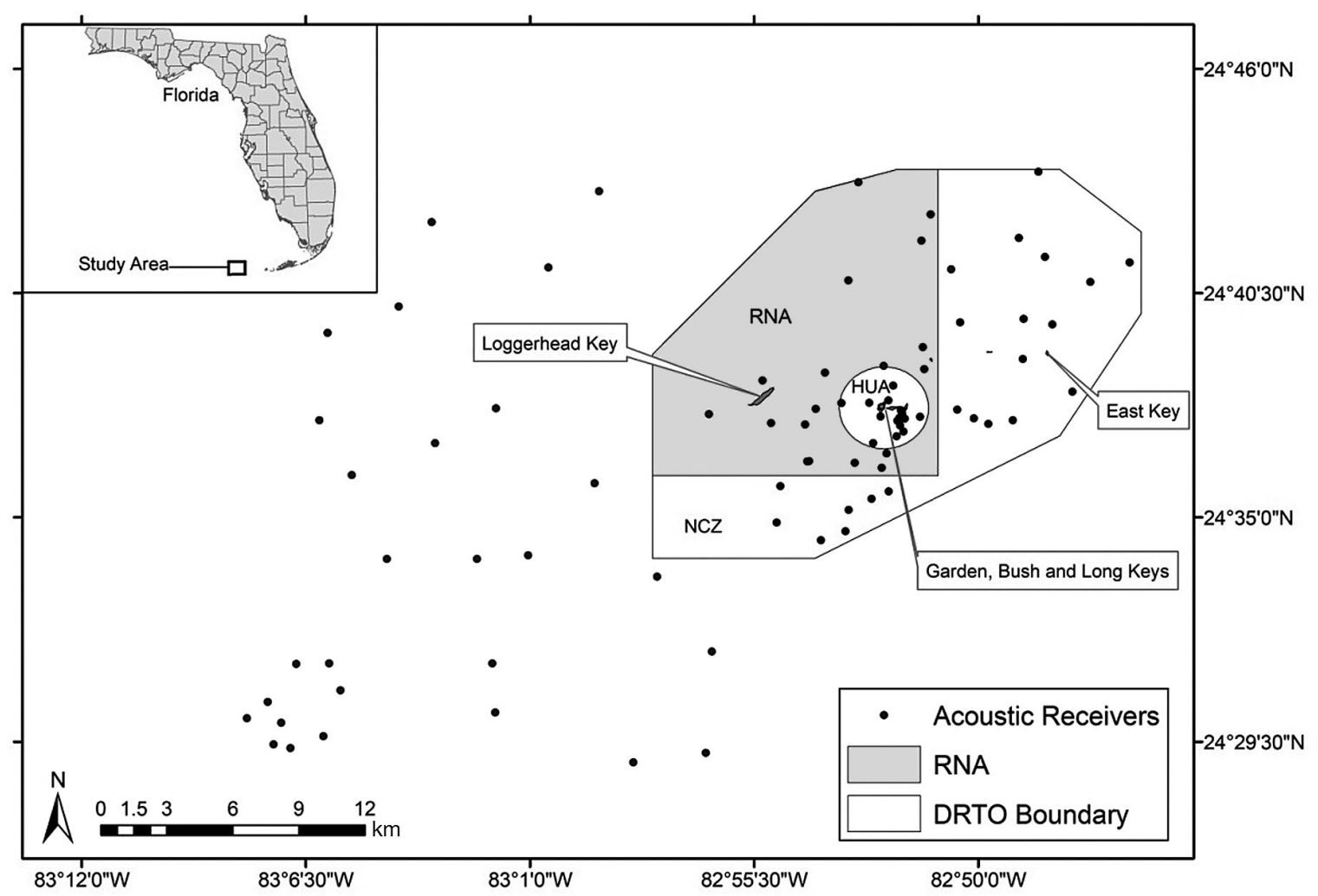

Fig. 1. Study area showing the islands, acoustic receiver array present at time of study, Dry Tortugas National Park (DRTO) boundary and the different management boundaries within. The area outside the research natural area (RNA), but within the park is the natural cultural zone (NCZ), which extends to the east and south of the RNA. There is also a $10.7 \mathrm{~km}^{2}$ area within the RNA designated as the historic adaptive-use zone (HAU) for a 1 mile radius around Garden Key that allows for human activities such as anchoring and fishing. This area is concentrated around Garden Key and Bush Key where human activities are the most common. There were 55 acoustic receivers in or within detection range $(200 \mathrm{~m})$ of the DRTO boundary. Of these, 18 were inside the RNA (with an additional 2 within detection range of the RNA), and another 15 were inside the HAU (with 1 additional receiver within detection range of the HAU) 
ging each animal, we took standard carapace measurements, including curved (CCL) and straight (SCL) carapace lengths. We weighed turtles with a spring scale and netting to the nearest $0.1 \mathrm{~kg}$ and took photographs to document carapace and skin anomalies.

We fitted a Wildlife Computers SPOT5 platform terminal transmitter (PTT) to each turtle. Each tag (2.5xAA model for Turtles A and $C_{i} 2 x A A$ model for Turtle B) had a saltwater switch and output of $0.5 \mathrm{~W}$. The 2 xAA model measured $79.7 \times 49.5 \times 18.1 \mathrm{~mm}$ (length $\times$ width $\times$ height) with a mass of $95 \mathrm{~g}$ in air, and the $2.5 \times A A$ model measured $71 \times 54 \times 24 \mathrm{~mm}$ with a mass of $115 \mathrm{~g}$ in air. Prior to transmitter application with Power-Fast ${ }^{\mathrm{TM}}$ 2-part marine epoxy, we removed epibionts (e.g. barnacles, algae) from the carapace of each turtle and sanded and cleaned the carapace with isopropyl alcohol. We streamlined attachment materials and minimized the epoxy footprint. The anticipated battery life of each tag was $1 \mathrm{yr}$, and each tag was programmed to operate continuously. All tagged turtles were released within $2 \mathrm{~h}$ at their capture location.

We outfitted 2 of the 3 turtles with Vemco V16-4L acoustic transmitters (25 $\mathrm{g}$ in air, $11 \mathrm{~g}$ in water; $16 \mathrm{~mm}$ diameter $\times 68 \mathrm{~mm}$ length) on the right rear carapace marginal scute. We prepared the area where the tag was to be affixed as with the satellite transmitters. To affix the acoustic transmitter, we used approximately half of 1 West Marine epoxy putty stick, mixed immediately prior to application. We let the streamlined epoxy dry for approximately $10 \mathrm{~min}$. The anticipated life of each tag was several years.

In DRTO and the surrounding areas of the TSER and TNER, several agencies maintain an array of acoustic receivers (Vemco VR2 and VR2W) spanning approximately $800 \mathrm{~km}^{2}$. A total of 83 acoustic receivers were active in this array during the study period (Fig. 1).

\section{Satellite-data filtering and analysis}

We archived and filtered location data with the satellite-tracking and analysis tool (STAT; Coyne \& Godley 2005). Turtle positions were determined with the Argos system, which classified each location message received into 1 of 6 location classes (LCs): 3, 2, 1, 0, A, or B. Argos assigns accuracy estimates of $<250 \mathrm{~m}$ for LC 3, 250 to $<500 \mathrm{~m}$ for LC 2,500 to $<1500 \mathrm{~m}$ for LC 1 , and $>1500 \mathrm{~m}$ for LC 0 ; for a satellite pass with 3 messages and 2 messages, the estimated accuracy is unknown and locations are tagged as
LC A and LC B, respectively (CLS 2011). Locations failing the Argos plausibility tests are tagged as Class Z (CLS 2011). All location data were filtered by Argos using the traditional least-squares location processing algorithm. Hays et al. (2001) and Vincent et al. (2002) found the accuracy of LC A to be comparable to LC 1 from Argos, so we included LC 3, 2, 1, 0 and $\mathrm{A}$ locations and filtered out $\mathrm{B}$ and $\mathrm{Z}$ locations. We also filtered out locations that required a straight-line travel speed $>5 \mathrm{~km} \mathrm{~h}^{-1}$; we selected this conservative filter based on results by Parker et al. (2009) who reported hawksbill travel speeds of 0.7 to $1.2 \mathrm{~km} \mathrm{~h}^{-1}$ during transit in a Hawaiian study site, as well as previous use of this speed filter in other hawksbill tracking studies (Troëng et al. 2005, Van Dam et al. 2007, Gaos et al. 2012; see also Luschi et al. 1998). Using ArcGIS 9.3 (ESRI 2007), we manually removed obviously erroneous points (e.g. those that 'zig-zagged' land or large areas of open water) and implausible locations remaining after the STAT filtering process. Additionally, for home range and core-use analyses, we removed points received after the turtle's last day within the DRTO boundary (assumed start of migration). From accepted Argos locations, we calculated inferred mean travel speeds during foraging for all turtles using the linear distances between 2 consecutive filtered locations in kilometers per hour.

To minimize autocorrelation in spatial analysis, we generated mean daily locations for each turtle from the accepted locations, following the methods of Seney \& Landry (2008). The resulting coordinates provided raw data for individual fixed kernel density estimation (KDE) analysis (e.g. Eckert et al. 2006, Seney \& Landry 2008). Kernel density is a non-parametric method used to identify 1 or more areas of disproportionately heavy use (i.e. core areas) within a home range boundary (for review see Worton 1987, 1989, White \& Garrott 1990, Laver \& Kelly 2008), with appropriate weighting of outlying observations. As Laver \& Kelly (2008) suggested, we implemented core-use analysis for each animal following Seaman \& Powell (1996) and Powell (2000), and report the $50 \%$ contour values at which core areas were delineated. We used the home range tools for ArcGIS extension (Rodgers et al. 2005) and the fixed kernel least-squares cross-validation smoothing factor $\left(h_{\mathrm{cv}}\right)$ for each KDE (Worton 1995, Seaman \& Powell 1996). When the variance of $x$ - and $y$-coordinates of the points were highly unequal, the data were rescaled before applying the kernel method. We used ArcGIS 9.3 to calculate the in-water area $\left(\mathrm{km}^{2}\right)$ within each contour and to plot the data. We used a $50 \% \mathrm{KDE}$ to represent the core area of activity (Hooge et al. 2001, 
Laver \& Kelly 2008). We combined overlapping areas of each $50 \% \mathrm{KDE}$ to create a common-use core area for all turtles. We overlaid the DRTO boundary and the RNA boundary on all resulting maps and summed location data with respect to both boundaries.

To test and quantify site fidelity, we used the spatial analyst and animal movement (AMAE) extension for ArcView 3.3. We used Monte Carlo random walk (MCRW) simulations to test for site fidelity (100 replicates), testing tracks for spatial randomness against randomly generated walks (Hooge et al. 2001, Mansfield et al. 2009). We bounded the range for random walks to 0-150 m depth to include only the realistic extent of the in-water habitat for our animals during the study period. Tracks exhibiting site fidelity indicate movements that are more spatially constrained rather than randomly dispersed (Hooge et al. 2001). A very small proportion of accepted turtle locations fell on land (4 points in total for all 3 turtles; $0.7 \%$ of filtered locations); this was likely due to a combination of satellite errors and changes in island shape for these highly dynamic small sandy islands at DRTO. We ran the kernel density tests and constrained random walk including these 4 points.

Corresponding water depths for turtle $50 \%$ coreuse areas were extracted from bathymetry raster data from the NOAA National Geophysical Data Center (GEODAS) US Coastal Relief Model Grids with 2 min resolution (www.ngdc.noaa.gov/mgg/gdas/ gd_designagrid.html, accessed 7 November 2011). Using ArcGIS 9.3, we calculated the mean water depth from the raster data for the common-use area.

\section{Acoustic telemetry analysis}

The detection distance of acoustic receivers can vary based on transmitter type, salinity and depth of water, ambient noise, presence of pycnoclines and thermoclines, and the behavior of the study animal (see Heupel et al. 2006). Receiver detection distances in our study area could range from 100 to $600 \mathrm{~m}$, depending on weather, terrain and sea state, so we used a conservative detection distance of $200 \mathrm{~m}$ for each receiver for all analyses. For each receiver with detections, we summed total detections and calculated the frequency of detections (number of turtledays). The receivers were deployed at variable times, so we standardized turtle-days at each receiver by dividing them by the total number of days the receiver was deployed.

To determine fine-scale movements and habitat use within the park by time of day, we converted the downloaded acoustic data from UTC to local time and then divided the detections into day and night categories. The average sunrise and sunset times at the study site during the tracking period were 07:06 and 18:43 h, so we calculated movements based on approximate times of 07:00 $\mathrm{h}$ for sunrise and 19:00 $\mathrm{h}$ for sunset.

We assessed the habitat characteristics at all receivers with turtle detections via snorkel and/or scuba diving in the summer and fall of 2011, collecting digital photographs to create records of habitat type in the immediate vicinity of each receiver. We classified receiver habitat types into 2 categories: sand/coral or seagrass. We then calculated the proportion of days that each receiver detected each tagged turtle during daytime and nighttime hours across all days that a given receiver was deployed. We analyzed the effect of depth, habitat type and time of day on this proportion for each animal separately using a logistic regression analysis with a random effect (e.g. a receiver effect) by implementing a SAS 9.1 GENMOD procedure; an $\alpha$-level of 0.05 was used to assess significance of these covariates.

We also determined the distance to the nearest coral reef platform for receivers with turtle detections. Using ArcGIS 9.3 and a layer of coral reef habitat for the DRTO area downloaded from the Florida Geographic Data Library (www.fgdl.org, accessed 1 December 2011; published by Florida Fish and Wildlife Conservation Commission, Fish and Wildlife Research Institute, St. Petersburg, on 28 June 2006), we compared the proportion of daytime and nighttime detections at each receiver to the distance from a coral reef platform with a correlation using the statistical software R (R Development Core Team 2011). Again, we used an $\alpha$-level of 0.05 to assess significance of these covariates.

\section{RESULTS}

\section{Turtles}

We captured 3 hawksbills Eretmochelys imbricata (Turtles A, B and C) in August 2008 on the relatively shallow flat near Bush Key; individuals ranged in size from 51.9 to $69.8 \mathrm{~cm}$ SCL (mean \pm SD: $61.53 \pm$

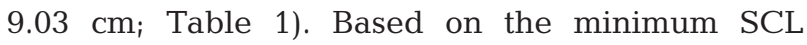
reported for adult hawksbills in Panama and Puerto Rico (i.e. $69.1 \mathrm{~cm}$ for males and 74.1 for females; Meylan et al. 2011), these turtles would be considered sub-adults at the time of capture. Sexual dimorphism in tail lengths was observed from $68.2 \mathrm{~cm}$ SCL 
Table 1. Eretmochelys imbricata. Body size and satellite-tracking details for 3 sub-adult hawksbill turtles captured during the foraging period in Dry Tortugas National Park (DRTO), South Florida, USA. No. of locations accepted: locations remaining after filtering raw Argos data as described in 'Materials and methods'. Nearest city of last location transmitted is given. SCL-tip: straight carapace length from nuchal scute to tip of carapace; KDE: kernel density estimate

\begin{tabular}{|c|c|c|c|c|c|c|}
\hline Turtle & $\begin{array}{l}\text { SCL-tip } \\
\text { (cm) }\end{array}$ & $\begin{array}{c}\text { Mass } \\
(\mathrm{kg})\end{array}$ & Tracking period (in DRTO) & $\begin{array}{c}\text { No. of days } \\
\text { tracked }\end{array}$ & $\begin{array}{l}\text { No. of locations re- } \\
\text { ceived (no. accepted } \\
\text { for } 50 \% \mathrm{KDE} \text { ) }\end{array}$ & $\begin{array}{l}\text { Last location } \\
\text { transmitted }\end{array}$ \\
\hline A & 51.9 & 18.1 & 7 Aug 2008-25 Jun 2010 (7 Aug 2008-24 May 2010) & 687 & $1179(91)$ & Playa Jibacoa, Cuba \\
\hline B & 62.9 & 27.0 & 10 Aug 2008-11 Jan 2011 (10 Aug 2008-10 Jul 2010) & 884 & $1249(309)$ & Key West, FL, USA \\
\hline $\mathrm{C}$ & 69.8 & 42.2 & 13 Aug 2008-29 Jun 2009 (13 Aug 2008-23 May 2009) & 320 & $743(114)$ & Playa Varadero, Cuba \\
\hline
\end{tabular}

for hawksbills in Puerto Rico (Van Dam \& Diez 1998b), and our largest turtle $(69.8 \mathrm{~cm} \mathrm{SCL})$ had a small tail as usually seen on females. However, it should be noted that growth rates and size at maturity can be variable across sites (Leon \& Diez 1999, Diez \& Van Dam 2002, Bell \& Pike 2012), and these measurements approach mature SCLs. Additionally, these turtles would have experienced continued growth over the tracking periods. We placed satellite transmitters on all 3 hawksbills, and acoustic tags on 2 of the 3 turtles (Turtles A and C).

\section{Satellite tracking and spatial habitat-use patterns}

Across all turtles, we obtained a total of 1891 turtle tracking days. During this time we received 3171 satellite-transmitted locations for the 3 tagged turtles from 7 August 2008 to 1 January 2011 (876 d). After the data filtering process, 514 locations remained for analysis of turtle habitat-use in DRTO (i.e. while in foraging mode; Table 1). The turtles were resident in DRTO for a range of 263 to $699 \mathrm{~d}$ before leaving the park (Table 1). The spatial extent of both daytimeand nighttime-filtered satellite locations was visually similar throughout DRTO. During this foraging period, mean inferred travel speed from the filtered locations for Turtles A, B, and C were 1.1, 1.2, and $1.3 \mathrm{~km} \mathrm{~h}^{-1}$, respectively.

The filtered data during the foraging period in DRTO provided 80, 252, and 67 mean daily locations for analysis for Turtles A, B, and C, respectively. The constrained version of a random walk site-fidelity test showed that the observed movements of all 3 turtles were more constrained than random movement paths (i.e. the proportion of the random movement paths with higher mean square distance values than the observed path was $>99 \%$ in all cases).

The size of the core-use areas (i.e. $50 \%$ KDEs) for the 3 hawksbills ranged from 9.2 to $21.5 \mathrm{~km}^{2}$ (mean \pm SD: $14.3 \pm 6.4 \mathrm{~km}^{2}$; Table 2). All core-use areas were concentrated around the flat surrounded by Garden Key, Bush Key, and Long Key (Fig. 2a). Notably, a large percentage (Turtles A, B, and C: 98, 60, and $98 \%$, respectively) of the core-use areas outside the RNA for the 3 turtles fell within a zone of the park called the historic adaptive-use zone (HAU; Fig. 2a); the HAU also comprised a large amount of the turtles' total core-use area (Turtles A, B, and C: 80, 36, and $61 \%$ ).

The common-use area was $6.1 \mathrm{~km}^{2}$ (Fig. 2b). The portion of the common-use area within the HAU accounted for $99.9 \%$ of the area outside the RNA and $95.0 \%$ of the total combined core-use area (Table 2 ).

Table 2. Eretmochelys imbricata. Kernel density estimate (KDE) details for 3 sub-adult turtles satellite-tracked during the foraging period in Dry Tortugas National Park (DRTO) for various lengths of time between August 2008 and July 2010. RNA: research natural area of DRTO; HAU: historic adaptive-use zone; dashes: not applicable; common use: combined overlapping area of each $50 \% \mathrm{KDE}$ for all turtles

\begin{tabular}{|c|c|c|c|c|c|c|}
\hline Turtle & $\begin{array}{l}\text { No. of days } \\
\text { tracked in } \\
\text { DRTO }\end{array}$ & $\begin{array}{c}\text { Total area } \\
\text { of } 50 \% \\
\mathrm{KDE} \\
\left(\mathrm{km}^{2}\right)\end{array}$ & $\begin{array}{c}\text { Area of } 50 \% \mathrm{KDE} \\
\text { in RNA }\left(\mathrm{km}^{2}\right) \\
\text { (percent of } \\
\text { total area) }\end{array}$ & $\begin{array}{c}\text { Area of } 50 \% \mathrm{KDE} \\
\text { out of RNA }\left(\mathrm{km}^{2}\right) \\
\text { (percent of } \\
\text { total area) }\end{array}$ & $\begin{array}{l}\text { Area of } 50 \% \mathrm{KDE} \\
\text { inside HAU }\left(\mathrm{km}^{2}\right) \\
\text { (percent of area } \\
\text { out of RNA) }\end{array}$ & $\begin{array}{l}\text { Bandwidth } \\
\left(h_{\mathrm{cv}}\right)\end{array}$ \\
\hline $\mathrm{A}$ & 655 & 9.24 & 1.78 (19) & $7.46(81)$ & $7.31(98)$ & 0.113 \\
\hline B & 699 & 21.45 & 8.42 (39) & $13.03(61)$ & $7.82(60)$ & 0.082 \\
\hline $\mathrm{C}$ & 263 & 12.20 & $4.55(37)$ & 7.65 (63) & 7.48 (98) & 0.078 \\
\hline Common use & - & 6.11 & $0.33(5)$ & 5.78 (95) & $5.78(99.9)$ & - \\
\hline
\end{tabular}



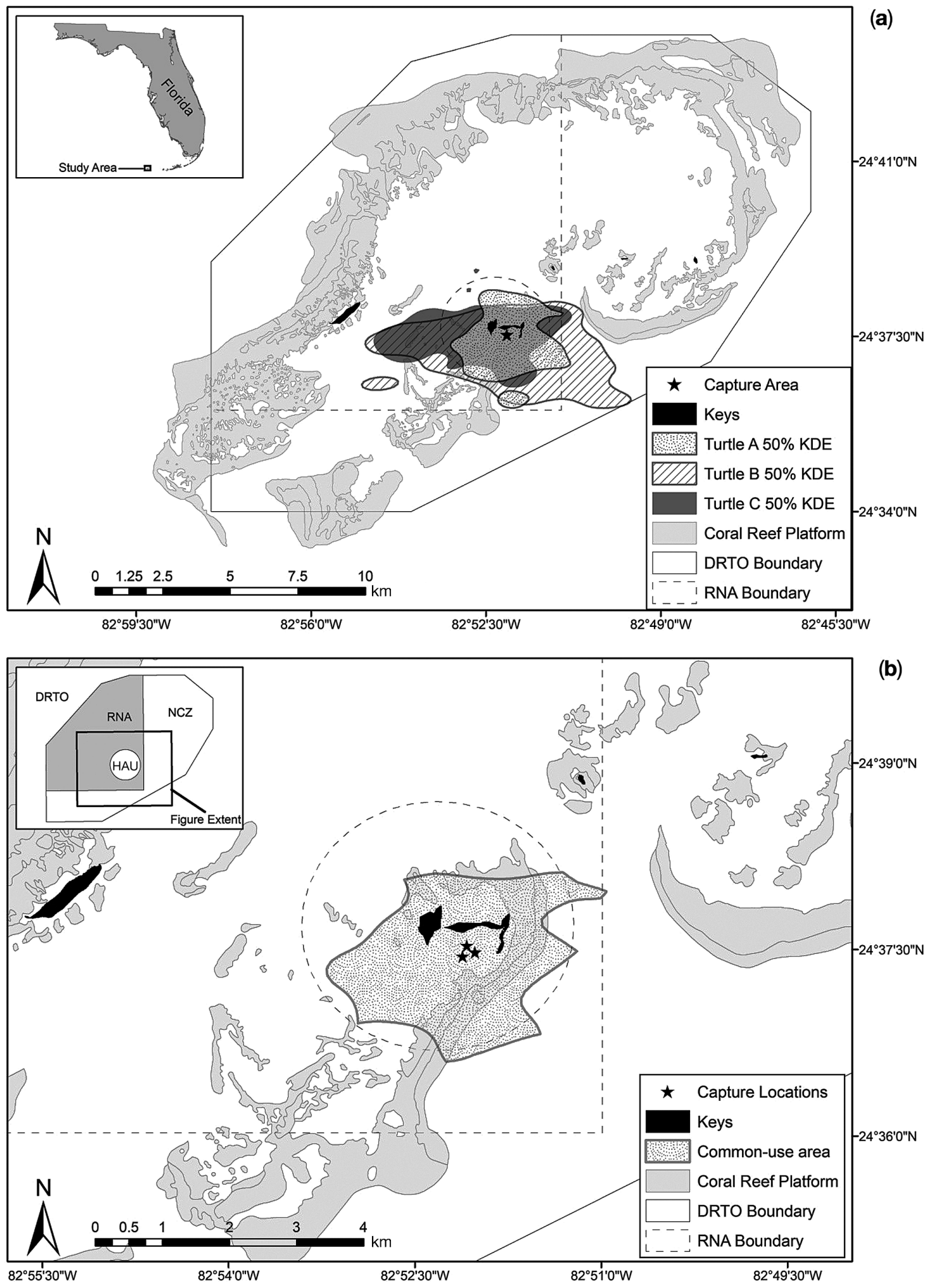

Fig. 2. Eretmochelys imbricata. (a) Turtle 50\% kernel density estimates (KDEs) as determined from satellite telemetry within Dry Tortugas National Park (DRTO). (b) Common-use area for 3 hawksbill turtles in DRTO. The coral reef platform was downloaded from the Florida Geographic Data Library (www.fgdl.org, accessed 1 December 2011; published by Florida Fish and Wildlife Conservation Commission, Fish and Wildlife Research Institute, St. Petersburg, on 28 June 2006). RNA: research natural area; NCZ: natural culture zone; HAU: historic adaptive-use zone 
Finally, water depths in the common-use area ranged from 0.1 to $8.0 \mathrm{~m}$ (mean $\pm \mathrm{SD}: 3.2 \pm 2.1 \mathrm{~m}$ ).

\section{Acoustic tracking}

We received a total of 10952 detections of 2 tagged turtles at 11 receiver stations in the DRTO area (Table 3, Fig. 3a). Turtle A's detection dates spanned 7 August 2008 to 1 January 2009 (8995 detections over $148 \mathrm{~d}$ at 9 receivers), whereas Turtle C's detection dates spanned a shorter time period: 31 August 2008 to 19 October 2008 (1957 detections over $50 \mathrm{~d}$ at 6 receivers; Table 3). Within the common-use area and $1000 \mathrm{~m}$ around it, there were 9 receivers with no detections.

The 11 receivers with turtle detections ranged in depth from 2.0 to $22.4 \mathrm{~m}$. Three of these receivers were immediately surrounded by seagrass, whereas the remaining 8 were in sand/coral habitat. The majority of Turtle A's detections (60\%) occurred at a receiver (R10; Table 3) in the HUA at $2.0 \mathrm{~m}$ depth and surrounded by seagrass. Similarly, the highest number of detections for Turtle C (34\%) occurred at another receiver (R1) in the HUA at $3.0 \mathrm{~m}$ depth and surrounded by seagrass; $25 \%$ of the remaining detections for Turtle $\mathrm{C}$ were at another receiver (R7) in the HUA at $2.0 \mathrm{~m}$ water depth surrounded by sand/coral (Table 3, Fig. 3b).

Logistic regression results indicated that the habitat effect was not significant for either acoustically tagged turtle $(p>0.05$; Table 4$)$. However, the effect

Table 3. Eretmochelys imbricata. Detections of 2 hawksbills (Turtles A and C) at acoustic receivers in Dry Tortugas National Park (DRTO) from 7 August 2008 to 1 January 2009. Location within the DRTO was the historic adaptive-use zone (HAU) in all cases. Habitat type: type of habitat immediately surrounding receiver, classified into 1 of 2 categories - sand/coral or seagrass

\begin{tabular}{|c|c|c|c|c|}
\hline \multirow{2}{*}{$\begin{array}{l}\text { Receiver } \\
\text { name }\end{array}$} & \multirow{2}{*}{$\begin{array}{l}\text { Depth } \\
\text { (m) }\end{array}$} & \multirow[t]{2}{*}{ Habitat type } & \multicolumn{2}{|c|}{ No. of detections } \\
\hline & & & Turtle A & Turtle C \\
\hline $\mathrm{R} 1$ & 3.0 & Seagrass & 0 & 674 \\
\hline $\mathrm{R} 2$ & 12.8 & Sand/coral & 0 & 232 \\
\hline R3 & 13.7 & Sand/coral & 507 & 0 \\
\hline $\mathrm{R} 4$ & 3.0 & Sand/coral & 602 & 0 \\
\hline R5 & 21.0 & Sand/coral & 126 & 0 \\
\hline R6 & 2.0 & Sand/coral & 187 & 334 \\
\hline $\mathrm{R} 7$ & 2.0 & Sand/coral & 16 & 497 \\
\hline R8 & 2.0 & Sand/coral & 242 & 0 \\
\hline R9 & 2.0 & Seagrass & 929 & 151 \\
\hline R10 & 2.0 & Seagrass & 5407 & 69 \\
\hline R11 & 22.4 & Sand/coral & 979 & 0 \\
\hline Total & & & 8995 & 1957 \\
\hline
\end{tabular}

of water depth was significant for 1 turtle (Turtle C, $p=0.024)$; the detection rate for this turtle was higher at receivers deployed in deeper water depths. Next, the effect of time was significant for both turtles $(\mathrm{p}<$ 0.001); the detection rate for both turtles was higher during daytime than during nighttime hours. For Turtle A, there was moderate inverse correlation between nighttime detection rate and proximity to reef platforms $(\mathrm{r}=-0.53, \mathrm{df}=7, \mathrm{p}=0.14)$, as well as a moderately high correlation between daytime detection rate and proximity to reef platforms $(\mathrm{r}=0.80$, df $=4, \mathrm{p}=0.05$ ) for Turtle $\mathrm{C}$.

\section{Turtle migrations}

We tracked Turtle A for $687 \mathrm{~d}$ beginning 7 August 2008 (Table 1). Turtle A was resident in DRTO for at least $655 \mathrm{~d}$ before migrating south towards Cuba on 27 May 2010 (Day 659 of tracking; Fig. 4). We received 37 locations after the turtle left DRTO. The turtle reached Cuban coastal waters (within $24 \mathrm{~km}$ of Cuba) on 4 June 2010 after traveling approximately $212 \mathrm{~km}$ for $8 \mathrm{~d}$. Four days later (8 June 2010), this turtle transmitted from the coastline of Cuba. The transmissions remained in a Cuban coastal area (including points onshore) for another $16 \mathrm{~d}$ (30 points) until the final transmission on 24 June 2010. Many of these last coastal points ( $40 \%$ versus $8 \%$ at foraging grounds) were of the highest location quality (LCs 3, 2 , and 1), which is unusual for turtles during foraging and indicates either multiple nesting attempts or that the turtle was onshore for a prolonged period. The last received transmission of high location quality (LC 3) was on land, followed by a lower quality location (LC A) received very close to shore, after which transmissions ceased.

We tracked Turtle B for $884 \mathrm{~d}$ beginning 10 August 2008 (Table 1). Turtle B was resident within DRTO for 699 d before migrating away after 10 July 2010. After the turtle left the park, we received only 2 filtered locations on 30 November 2010 (Day 843 of tracking) and 14 December 2010 from east of the DRTO boundary in waters near Key West (Fig. 4); after this date, no further transmissions were received.

We tracked Turtle C for $320 \mathrm{~d}$ (13 August 2008 to 18 May 2009; Table 1). Turtle C was resident in DRTO for at least $263 \mathrm{~d}$ before migrating south toward Cuba on 4 May 2009 (Day 265 of tracking); we received 37 locations during this migration. The turtle reached Cuban coastal waters on 12 May 2009 (within $35 \mathrm{~km}$ of Cuba's northern coast; Fig. 4) after traveling approximately $440 \mathrm{~km}$ for $14 \mathrm{~d}$ (4 to 18 May 2009). The 


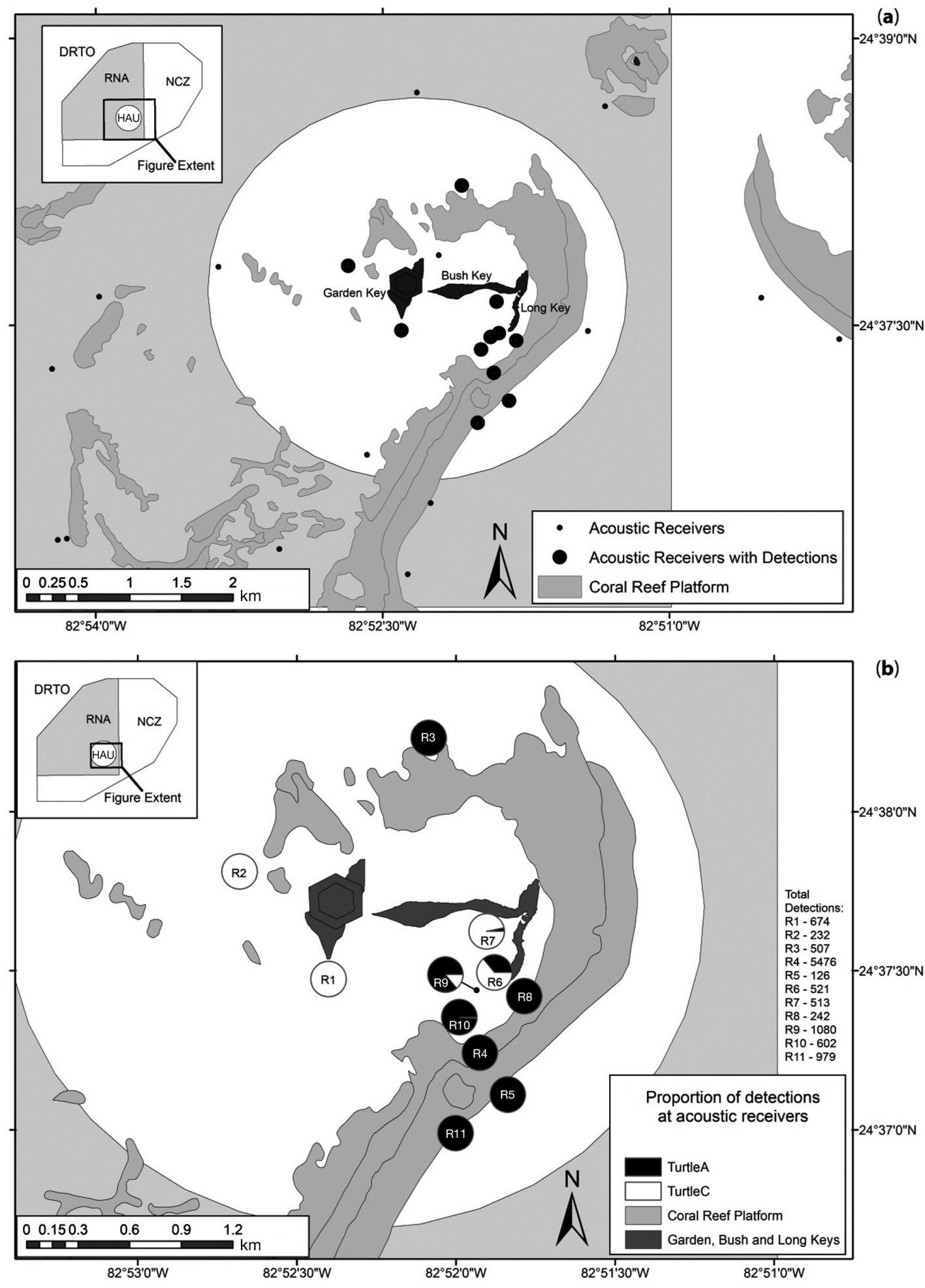

Fig. 3. Eretmochelys imbricata. (a) Close-up of area within the park with acoustic receiver detections; receivers with detections are shown larger. (b) Detections for 2 acoustically tagged turtles (Turtles A and C); proportion of detections by turtle is shown with a pie chart at each receiver location, with combined detections totaled to the right of the figure. Receivers are numbered R1 to R11 (see Table 3). All receivers with detections occurred within the historic adaptive-use zone (HAU). The coral reef platform shown was downloaded from the Florida Geographic Data Library (www.fgdl.org, accessed 1 December 2011; published by Florida Fish and Wildlife Conservation Commission, Fish and Wildlife Research Institute, St. Petersburg, on 28 June 2006), and used in the correlation described in 'Materials and methods'. RNA: research natural area; NCZ: natural cultural zone 
Table 4. Eretmochelys imbricata. Estimated model parameters of logistic regression to predict detection rate at acoustic receivers (number of detected days per number of days each receiver was deployed) by habitat type (seagrass or sand/coral, seagrass was used as the base category), depth, and time (daytime or nighttime; nighttime was used as the base category). Bold: significant at $\alpha=0.05$

\begin{tabular}{|c|c|c|c|c|c|c|c|}
\hline Turtle & Parameter & Estimate & $\mathrm{SE}$ & $\begin{array}{c}\text { Lower } \\
\text { CI }\end{array}$ & $\begin{array}{l}\text { Upper } \\
\text { CI }\end{array}$ & $Z$ & $\mathrm{p}$-value \\
\hline \multirow[t]{4}{*}{ A } & Intercept & -2.406 & 0.445 & -3.278 & -1.533 & -5.40 & $<0.001$ \\
\hline & Habitat & -0.776 & 0.685 & -2.118 & 0.567 & -1.13 & 0.258 \\
\hline & Depth & -0.044 & 0.030 & -0.103 & 0.015 & -1.45 & 0.146 \\
\hline & Time & 1.781 & 0.397 & 1.002 & 2.560 & 4.48 & $<0.001$ \\
\hline \multirow[t]{4}{*}{$\mathrm{C}$} & Intercept & -3.183 & 0.418 & -4.003 & -2.363 & -7.61 & $<0.001$ \\
\hline & Habitat & -0.232 & 0.241 & -0.704 & 0.240 & -0.96 & 0.336 \\
\hline & Depth & -0.072 & 0.032 & -0.133 & -0.010 & -2.26 & 0.024 \\
\hline & Time & 1.879 & 0.346 & 1.201 & 2.557 & 5.43 & $<0.001$ \\
\hline
\end{tabular}

\section{DISCUSSION}

\section{Turtle core-use areas, habitat use, and daily activity patterns}

Using both satellite and acoustic tracking, our results provide the first published summary of hawksbill Eretmochelys imbricata core-use areas in the continental United States. Compared to home-range estimates for hawksbills tagged elsewhere and in different size-classes, our results show that the 3 turtles tagged at DRTO had core-use areas ranging from 9.2 to $21.5 \mathrm{~km}^{2}$. Previously reported home-range estimates for wild day after the turtle's arrival in Cuban waters (13 May 2009), we received locations on land potentially from a nesting event or false crawl (abandoned nesting attempt). A few days later (16 May 2009), we received another location from onshore; however, from that point until 20 June 2009 we received an additional 137 points (unfiltered), all consistently from onshore. Before the final transmission, the locations from Argos suggested extended periods on land, including points along a major road and from within a village near Varadero Beach on the north coast of Cuba. adult hawksbills were 2.0 to $49.5 \mathrm{~km}^{2}$ in Barbados (Horrocks et al. 2001) and 0.5 to $2.0 \mathrm{~km}^{2}$ in Hawaii (Parker et al. 2009); both of these estimates were determined using a minimum convex polygon (MCP) approach. The few studies estimating home ranges for juvenile hawksbills have generally found areas of $1 \mathrm{~km}^{2}$ or less (0.07 to $0.14 \mathrm{~km}^{2}$ in Puerto Rico [Van Dam \& Diez 1998a], $1.2 \mathrm{~km}^{2}$ in Mexico [see Cuevas et al. 2007], 0.15 to $0.56 \mathrm{~km}^{2}$ in Honduras [Berube 2010], and $545 \pm 514 \mathrm{~m}$ mean straight-line recapture distance in the Cayman Islands [Blumenthal et al. 2009b]). In a comparison of home range size to turtle size, Scales et al. (2011) used acoustic tracking and MCP analysis to show a positive correlation, with homerange estimates for juveniles (33.0 to $48.6 \mathrm{~cm} \mathrm{CCL)} \mathrm{similar} \mathrm{to} \mathrm{pre-}$ vious estimates $\left(0.05\right.$ to $\left.1.11 \mathrm{~km}^{2}\right)$, while 2 larger individuals had home ranges of $2.6 \mathrm{~km}^{2}(48.5 \mathrm{~cm}$ $\mathrm{CCL}$ ) and $4.04 \mathrm{~km}^{2}$ (50.8 cm CCL).

Our core-use area estimate was substantially larger than most previously reported $\left(\sim 1 \mathrm{~km}^{2}\right.$ or less) home-range sizes for immature hawksbills and the 0.5 to $2.0 \mathrm{~km}^{2}$ adult home-range estimate from Hawaii (Parker et al. 2009). However, this small sample of hawksbill home ranges fell within the adult home-range estimate from Barbados (1.96 to $49.5 \mathrm{~km}^{2}$; Horrocks et al. 2001). Our measures of home-range size may be larger due to the larger
Fig. 4. Eretmochelys imbricata. Migrations away from Dry Tortugas National Park (DRTO) for 3 satellite-tracked sub-adult hawksbills. Lines connect filtered satellite locations by date. Turtles A and C ceased transmitting upon arrival in Cuba (many of the last points occurred on land); the migration of Turtle $\mathrm{C}$ to Cuba is shown. Turtle B ceased transmission west of Key West, FL (shown by 2 dots with a hatched line to denote inferred tracking path due to gap in transmissions) 
body size of sub-adults compared to juveniles, as the results of Scales et al. (2011) suggest. As well, homerange size at DRTO may be larger than that for hawksbills at other sites simply due to DRTO-specific habitat configurations.

Acoustic tracking allowed for determination of finescale patterns of habitat use and movements and were confirmed via Argos satellite tracking. While filtered Argos locations failed to show visually distinct spatial differences in day and night locations, we were able to detect this difference with the fine-scale acoustic data; our tagged hawksbills were more active within their core-use areas during the day. This could indicate more active foraging behavior during the day and possibly resting behavior at night, which would support the findings of Blumenthal et al. (2009b) in the Cayman Islands; through direct visual surveys they found that hawksbills rested on the bottom and under coral reef ledges during the night.

Blumenthal et al. (2009b) found a weak but highly significant positive correlation between turtle size and depth of water at capture. Our study shows some support for this finding as our largest turtle (Turtle C) was detected spending significantly more time near deeper acoustic receivers, exhibiting a possible preference for deeper water. Habitat type at the receiver site was not an important predictor of turtle presence. However, using acoustic detection data, we determined that turtle preference closer to platform reef habitat existed, at least within nighttime hours. Additionally, a high proportion of detections (60\%, Turtle $A_{;} 34 \%$, Turtle C) for hawksbills occurred at receivers immediately surrounded by seagrass; this result indicates that either the hawksbills were foraging in this habitat or often moving through it. Determining the habitat type within the entire $200 \mathrm{~m}$ circumference of each receiver was not within the scope of the present study, and it is possible that the turtles were spending time in mixed or different habitats within range of a given receiver. Blumenthal et al. (2009b) sighted hawksbills in Little Cayman (14\%) and Grand Cayman (26\%) in habitats in which they did not feed (i.e. uncolonized hardbottom). Additionally, recent studies have shown local adaptation of hawksbills to other habitat types (e.g. mangroves in the eastern Pacific; Gaos et al. 2012), indicating that this species is not strictly an obligate coral reefdweller. A detailed geo-referenced habitat map in association with acoustic and accelerometer data could help to decipher even finer-scale habitat use by hawksbills in DRTO and whether they rest, forage, or simply move through areas with a high rate of turtle detections.

\section{Turtle size and possible nesting activities}

Reported growth rates in the Caribbean region (Cayman Islands, United States Virgin Islands, Bahamas, and Puerto Rico) for hawksbills range from negligible to $15.7 \mathrm{~cm} \mathrm{yr}^{-1}$ for sizes ranging from 20 to $84.5 \mathrm{~cm}$ SCL (Bjorndal \& Bolten 1988, Diez \& Van Dam 2002). Within this range, 1.0 to $4.5 \mathrm{~cm} \mathrm{yr}^{-1}$ was reported for turtles of 50 to $60 \mathrm{~cm} \mathrm{SCL}$ and 1.0 to $4.0 \mathrm{~cm} \mathrm{yr}^{-1}$ for turtles of 60 to $70 \mathrm{~cm} \mathrm{SCL} \mathrm{(Bjorndal} \mathrm{\&}$ Bolten 1988, Boulon 1994, Diez \& Van Dam 2002, Blumenthal et al. 2009b). Growth rate varied by turtle size (i.e. the rate decreased as turtles grew larger) and location (Diez \& Van Dam 2002), indicating either density-dependent or habitat-quality factors may affect growth rates.

Turtle A, the smallest of our 3 hawksbills $(51.9 \mathrm{~cm}$ SCL upon capture), ceased transmitting in a coastal area of Cuba 687 d (1.8 yr) after tagging. Current estimates for hawksbill growth rates in the Caribbean suggest this turtle may have reached a maximum possible size of $60 \mathrm{~cm}$ SCL by the last transmission date. Turtle B measured $62.9 \mathrm{~cm}$ SCL upon first capture and may have grown to $72.5 \mathrm{~cm}$ SCL over the $884 \mathrm{~d}$ (2.4 yr) of tracking; however, the actual size was likely smaller as growth rates begin to slow when a turtle reaches $70 \mathrm{~cm}$ SCL. Turtle C, the largest of our hawksbills (69.8 cm SCL), was tracked for $263 \mathrm{~d}(0.7 \mathrm{yr})$ and may have grown to $71.7 \mathrm{~cm}$ SCL on arrival in Cuba.

While $50 \%$ of hawksbill nesters in Cuba were mature at 76 to $80 \mathrm{~cm} \mathrm{SCL}$, the smallest known hawksbill nester from the Cuban archipelago measured $58.5 \mathrm{~cm}$ SCL (Moncada et al. 1999). Additionally, the smallest recorded successful hawksbill nester in the United States Virgin Islands, one of the largest remaining nesting grounds for hawksbills, was $68.7 \mathrm{~cm}$ SCL, $73.6 \mathrm{~cm}$ CCL (I. Lundgren, National Park Service, pers. comm.). It is therefore possible that we documented migration from DRTO to possible nesting grounds for the first nesting attempts for Turtles A and $\mathrm{C}$, at projected sizes of 60 and $71.7 \mathrm{~cm} \mathrm{SCL}$, respectively. By the time Turtle B ceased transmitting it had not reached an obvious nesting ground, and the reasons for this movement are unclear. This turtle may have made movements towards an as yet unknown breeding ground off Key West, Florida.

\section{Hawksbill harvesting in Cuba}

Historically harvested around the world for subsistence, medicine, and oil, hawksbills have been harvested mainly to supply international trade in their 
thick, keratinized scutes, commonly referred to as 'tortoiseshell' or 'bekko', a highly valued raw material due to the beautiful pattern and plastic-like texture (Carillo et al. 1999). Hawksbills have been harvested in Cuban waters since the 1500 s, but during the 20th century harvest was primarily part of a fishery to supply international trade (see Mortimer et al. 2007).

Cuba traded bekko with Japan until 1995 (see Mortimer et. al 2007), despite the listing as an Appendix I species on the Convention on International Trade in Endangered Species (CITES) in 1975, which prohibited all trade. Reports in 1999 and 2000 claimed that the primary purpose for the turtle fishery in Cuba was domestic consumption (Carillo et al. 1999), and the fishery remained open until the end of January, 2008, when the WWF-Canada and the Canadian International Development Agency (CIDA) worked with the Cuban Ministry of Fisheries to ban the harvesting of all marine turtles (http://wwf.ca/ about_us/successes/hawksbill; accessed 4 April 2011).

Although Cuba's harvesting history is extensive, there have been many recent moves toward conservation of hawksbills, including implementation of conservation and community outreach programs (e.g. Bretos et al. 2006) and the creation of new marine parks (e.g. Jardines de la Reina created in 2010). WIDECAST (Wider Caribbean Sea Turtle Conservation Network, www.widecast.org) brings together biologists, managers, community leaders, and educators throughout the Caribbean to address sea turtle declines and has programs running in Cuba to both study and conserve sea turtles. Yet, despite these and other steps toward conservation and a sustainable fishery, illegal subsistence fishing may remain a problem for some areas of Cuba, including conservation sites (J. Gerhartz [Director, WWF Cuba Field Office], pers. comm. [15 June 2009], Bretos et al. 2006).

\section{Conservation implications}

In addition to revealing patterns of habitat use within DRTO, satellite telemetry enabled us to determine migration paths and potential fates of turtles, possibly indicating where future conservation efforts should be focused. Turtle C's satellite transmitter was found with fishermen in a village near Varadero Beach on the north coast of Cuba (J. Gerhartz [Director, WWF Cuba Field Office] pers. comm., 15 June 2009). Another study satellite-tracked a loggerhead turtle Caretta caretta from off the coast of western
Florida to northwest Cuba, where the last 2 mo of transmissions came from on land in a coastal town (Girard et al. 2009). Additionally, Sasso et al. (2011) used pop-up archival transmitting tags on 30 loggerheads from the east coast of Florida, and, within 4 mo, 1 of these transmitted from well inland in Cuba. It remains unclear whether Turtle A was harvested or simply stopped transmitting very soon after a nesting event.

Richardson et al. (1999) pointed out that with a reproductive rate of 288 eggs $\mathrm{yr}^{-1}$, adult female hawksbills must be allowed to reproduce for at least $9 \mathrm{yr}$ (4.1 nesting seasons individual ${ }^{-1}$ ) to maintain the population. Combined with a generally low hatchling sea turtle survival rate (Heppell 1998), some animals must continue to be reproductively active for several decades or more to balance the early mortality of other individuals. The hawksbill's 'Critically Endangered' status is likely the result of prolonged harvesting of multiple life stages and a resulting lack of long-term reproduction necessary to maintain populations. Further, repopulation of depleted stocks of hawksbills in one foraging ground may not occur if turtles are harvested in other nesting or foraging grounds.

\section{CONCLUSIONS}

Even with a low sample size, our results revealed patterns of hawksbill residence in DRTO. We also found previously unknown links between hawksbills in a United States National Park and both Cuba and an area of the Florida Keys (i.e. off Key West). Moreover, we estimated some of the first home ranges and core-use areas for sub-adult hawksbills. Additional tracking of hawksbills from this site will reveal whether the habitat-use and movement patterns documented here are similar to those for a larger number of turtles. Although our acoustic tracking data did not reveal obvious habitat preferences, our analysis indicated that hawksbills were more active during the day within their core-use area. Additionally, the acoustic data revealed that the largest tagged hawksbill spent more time near deeper receivers. Future capture and survey efforts for hawksbills at deeper in-water sites in DRTO may be warranted. Finally, closer examination of hawksbills is needed once they leave the protected area of DRTO. Thus, due to the migratory nature of hawksbills, our results echo Blumenthal et al.'s (2006) findings that effective protection for the species must include international conservation efforts. 
Acknowledgements. All work was permitted by National Marine Fisheries Service Permit 13307-03 (issued to K.M.H.) and Dry Tortugas National Park Permits DRTO-2008-SCI0008 and DRTO-2010-SCI-0009 (issued to K.M.H.). All turtle handling and sampling was performed according to USGS Institutional Animal Care Protocol USGS-SESC-IACUC 2011-05. Funding for this work was provided by the National Park Service, USGS Priority Ecosystem Science Program, and USGS Coastal and Marine Geology Program. We acknowledge the use of www.seaturtle.org and the satellite-tracking and analysis tool (STAT). We thank K. Ludwig and J. Sanford for help catching and working up turtles, and J. Douglass, C. Douglass, J. Spade, and T. Gottshall for logistical support at DRTO. Any use of trade, product, or firm names is for descriptive purposes only and does not imply endorsement by the United States Government.

\section{LITERATURE CITED}

Arendt MD, Lucy JA, Evans DA (2001) Diel and seasonal activity patterns of adult tautog, Tautoga onitis, in lower Chesapeake Bay, inferred from ultrasonic telemetry. Environ Biol Fishes 62:379-391

Bass AL (1999) Genetic analysis to elucidate the natural history and behavior of hawksbill turtles (Eretmochelys imbricata) in the wider Caribbean: a review and reanalysis. Chelonian Conserv Biol 3:195-199

Bass AL, Good DA, Bjorndal KA, Richardson JI, Hillis ZM, Horrocks JA, Bowen BW (1996) Testing models of female reproductive migratory behaviour and population structure in the Caribbean hawksbill turtle, Eretmochelys imbricata, with mtDNA sequences. Mol Ecol 5:321-328

Bell I, Pike DA (2012) Somatic growth rates of hawksbill turtles Eretmochelys imbricata in a northern Great Barrier Reef foraging area. Mar Ecol Prog Ser 446:275-283

Benson SR, Eguchi T, Foley DG, Forney KA and others (2011) Large-scale movements and high-use areas of western Pacific leatherback turtles, Dermochelys coriacea. Ecosphere 2:art84. doi:10.1890/ES11-00053.1

Berube MD (2010) Home range and foraging ecology of juvenile hawksbill sea turtles around Roatan, Honduras. Dissertation, Loma Linda University, Loma Linda, CA

Bjorndal KA, Bolten AB (1988) Growth rates of immature green turtles, Chelonia mydas, on feeding grounds in the southern Bahamas. Copeia 1988:555-564

Bjorndal KA, Carr A, Meylan AB, Mortimer JA (1985) Reproductive biology of the hawksbill Eretmochelys imbricata at Tortuguero, Costa Rica, with notes on the ecology of the species in the Caribbean. Biol Conserv 34:353-368

Blumenthal JM, Solomon JL, Bell CD, Austin TJ and others (2006) Satellite tracking highlights the need for international cooperation in marine turtle management. Endang Species Res 2:51-61

Blumenthal JM, Abreu-Grobois FA, Austin TJ, Broderick AC and others (2009a) Turtle groups or turtle soup: dispersal patterns of hawksbill turtles in the Caribbean. Mol Ecol 18:4841-4853

Blumenthal JM, Austin TJ, Bell CDL, Bothwell JB and others (2009b) Ecology of hawksbill turtles, Eretmochelys imbricata, on a western Caribbean foraging ground. Chelonian Conserv Biol 8:1-10

> Blumenthal JM, Austin TJ, Bothwell JB, Broderick AC and others (2009c) Diving behavior and movements of juvenile hawksbill turtles Eretmochelys imbricata on a Carib- bean coral reef. Coral Reefs 28:55-65

Boulon RH (1994) Growth rates of wild juvenile hawksbill turtles, Eretmochelys imbricata, in St. Thomas, United States Virgin Islands. Copeia 1994:811-814

- Bowen BW, Bass AL, Garcia-Rodriguez A, Diez CE and others (1996) Origin of hawksbill turtles in a Caribbean feeding area as indicated by genetic markers. Ecol Appl 6:566-572

> Bowen BW, Grant WS, Hillis-Starr Z, Shaver DJ, Bjorndal KA, Bolten AB, Bass AL (2007) Mixed-stock analysis reveals the migrations of juvenile hawksbill turtles (Eretmochelys imbricata) in the Caribbean Sea. Mol Ecol 16:49-60

Bretos F, Diaz-Fernandez R, Donnelly M (2006) Second international Guanahacabibes sea turtle conservation workshop. Mar Turtle Newsl 113:14-15

Carillo E, Webb GJW, Manolis SC (1999) Hawksbill turtles (Eretmochelys imbricata) in Cuba: an assessment of the historical harvest and its impacts. Chelonian Conserv Biol 3:264-280

Carr A, Hirth H, Ogren L (1966) The ecology and migrations of sea turtles. 6. The hawskbill turtle in the Caribbean Sea. Am Mus Novit 2248:1-29

CLS (Collecte Localisation Satellites) (2011) Argos user's manual: worldwide tracking and environmental monitoring by satellite, 19 August 2011 update. CLS, Toulouse. Available at: www.argos-system.org/web/en/76-user-smanual.php

Coyne MS, Godley BJ (2005) Satellite tracking and analysis tool (STAT): an integrated system for archiving, analyzing and mapping animal tracking data. Mar Ecol Prog Ser 301:1-7

- Cuevas E, Liceaga-Correa MA, Garduno-Andrade M (2007) Spatial characterization of a foraging area for immature hawksbill turtles (Eretmochelys imbricata) in Yucatan, Mexico. Amphib-Reptil 28:337-346

> Diez CE, Van Dam RP (2002) Habitat effect on hawksbill turtle growth rates on feeding grounds at Mona and Monito Islands, Puerto Rico. Mar Ecol Prog Ser 234:301-309

Eckert KA (2002) WIDECAST: visualizing a future for people and sea turtles in the Caribbean Sea. Mar Turtle Newsl 98:11-12

- Eckert S, Bagley D, Kubis S, Ehrhart L, Johnson C, Stewart K, Defreese D (2006) Inter-nesting, post-nesting movements and foraging habitats of leatherback sea turtles (Dermochelys coriacea) nesting in Florida. Chelonian Conserv Biol 5:239-248

ESRI (Environmental Systems Research Institute) (2007) ArcGIS 9.3 GIS. ESRI, Redlands, CA

> Gaos AR, Lewison RL, Yanez IL, Wallace BP and others (2012) Shifting the life-history paradigm: discovery of novel habitat use by hawksbill turtles. Biol Lett 8:54-56

> Girard C, Tucker AD, Calmettes B (2009) Post-nesting migrations of loggerhead sea turtles in the Gulf of Mexico: dispersal in highly dynamic conditions. Mar Biol 156:1827-1839

Godley BJ, Blumenthal JM, Broderick AC, Coyne MS, Godfrey $\mathrm{MH}$, Hawkes LA, Witt MJ (2008) Satellite tracking of sea turtles: Where have we been and where do we go next? Endang Species Res 4:3-22. doi:10.3354/esr00060

Hart KM, Hyrenbach KD (2009) Satellite telemetry of marine megavertebrates: the coming of age of an experimental science. Endang Species Res 10:9-20

Hays GC, Akesson S, Godley BJ, Luschi P, Santidrian P (2001) The implications of location accuracy for the inter- 
pretation of satellite-tracking data. Anim Behav 61: 1035-1040

> Heppell SS (1998) Application of life-history theory and population model analysis to turtle conservation. Copeia 367-375

Heupel MR, Semmens JM, Hobday AJ (2006) Automated acoustic tracking of aquatic animals: scales, design and deployment of listening station arrays. Mar Freshw Res 57:1-13

Hooge PN, Eichenlaub W, Hooge ER (2001) Animal movement 2.5. U.S. Geological Survey, Alaska Biological Science Center, Anchorage

Horrocks JA, Vermeer LA, Krueger B, Coyne MS, Schroeder B, Balazs GH (2001) Migration routes and destination characteristics of post-nesting hawksbill turtles satellitetracked from Barbados, West Indies. Chelonian Conserv Biol 4:107-114

- Kamel SJ, Mrosovsky N (2005) Repeatability of nesting preferences in the hawksbill sea turtle, Eretmochelys imbricata, and their fitness consequences. Anim Behav 70: $819-828$

> Laver PN, Kelly MJ (2008) A critical review of home range studies. J Wildl Manag 72:290-298

León YM, Bjorndal KA (2002) Selective feeding in the hawksbill turtle, an important predator in coral reef ecosystems. Mar Ecol Prog Ser 245:249-258

Leon YM, Diez CE (1999) Population structure of hawksbill turtles on a foraging ground in the Dominican Republic. Chelonian Conserv Biol 3:230-236

Luschi P, Hays GC, Del Seppia C, Marsh R, Papi F (1998) The navigational feats of green sea turtles migrating from Ascension Island investigated by satellite telemetry. Proc Biol Sci 265:2279-2284

Mallinson D, Hine A, Hallock P, Locker S and others (2003) Development of small carbonate banks on the south Florida platform margin: response to sea level and climate change. Mar Geol 199:45-63

> Mansfield KL, Saba VS, Kenaith JA, Musick JA (2009) Satellite tracking reveals a dichotomy in migration strategies among juvenile loggerhead turtles in the Northwest Atlantic. Mar Biol 156:2555-2570

Meylan A (1988) Spongivory in hawksbill turtles: a diet of glass. Science 239:393-395

Meylan AB (1999) International movements of immature and adult hawksbill turtles (Eretmochelys imbricata) in the Caribbean region. Chelonian Conserv Biol 3:189-194

Meylan AB, Donnelly M (1999) Status justification for listing the hawksbill turtle (Eretmochelys imbricata) as critically endangered on the 1996 IUCN red list of threatened animals. Chelonian Conserv Biol 3:200-224

> Meylan PA, Meylan AB, Gray JA (2011) The ecology and migrations of sea turtles. 8. Tests of the developmental habitat hypothesis. Bull Am Mus Nat Hist 357:1-70

Moncada F, Carrillo E, Saenz A, Nodarse G (1999) Reproduction and nesting of the hawksbill turtle, Eretmochelys imbricata, in the Cuban Archipelago. Chelonian Conserv Biol 3:257-263

Mortimer JA, Donnelly M (2008) Eretmochelys imbricata. Available at: www.iucnredlist.org (accessed 29 September 2011)

> Mortimer JA, Meylan PA, Donnelly M (2007) Whose turtles are they, anyway? Mol Ecol 16:17-18

Mortimer JA, Gerlach J, Summerton P (2012) Long distance migrations of hawksbills tagged as juveniles at Aldabra Atoll: confirmation from digital photography. Mar Turtle
Newsl 129:11-13

National Park Service (2006) Dry Tortugas National Parkspecial regulations. Fed Regist 71:76154-76166

NMFS \& USFWS (National Marine Fisheries Service and United States Fish and Wildlife Service) (1998) Recovery plan for U.S. Pacific populations of the hawksbill turtle (Eretmochelys imbricata). NMFS, Silver Spring, MD

NMFS \& USFWS (National Marine Fisheries Service and United States Fish and Wildlife Service) (1993) Recovery plan for hawksbill turtles in the U.S. Caribbean Sea, Atlantic Ocean, and Gulf of Mexico. NMFS, St. Petersburg, FL

NMFS SEFSC (National Marine Fisheries Service Southeast Fisheries Science Center) (2008) Sea turtle research techniques manual. NOAA Memo NMFS-SEFSC-579, Washington, DC

Okuyama J, Shizmizu T, Abe O, Yosedo K, Arai N (2005) Dispersal processes of head-started hawksbill turtles (Eretmochelys imbricata) in the Yaeyama Islands waters, Okinawa, Japan. In: Proc 2nd Int Symp on SEASTAR2000 and Asian Bio-logging Science (The 6th SEASTAR2000 Workshop), Bangkok, p 63-68

> Parker DM, Balazs GH, King CS, Katahira L, Gilmartin W (2009) Short-range movements of hawksbill turtles (Eretmochelys imbricata) from nesting to foraging areas within the Hawaiian Islands. Pac Sci 63:371-382

Parmenter CJ (1983) Reproductive migration in the hawksbill turtle (Eretmochelys imbricata). Copeia 271-273

Powell RA (2000) Animal home ranges and territories and home range estimators. In: Boitani L, Fuller TK (eds) Research techniques in animal ecology: controversies and consequences. Columbia University Press, New York, NY, p 65-110

R Development Core Team (2011) R: a language and environment for statistical computing. R Foundation for Statistical Computing, Vienna. Available at: www.R-project.org/

Richardson JI, Bell R, Richardson TH (1999) Population ecology and demographic implications drawn from an 11year study of nesting hawksbill turtles, Eretmochelys imbricata, at Jumby Bay, Long Island, Antigua, West Indies. Chelonian Conserv Biol 3:244-250

Rodgers AR, Carr AP, Smith L, Kie JG (2005) HRT: home range tools for ArcGIS. Ontario Ministry of Natural Resources, Centre for Northern Forest Ecosystem Research, Thunder Bay

Sasso CR, Epperly SP, Johnson C (2011) Annual survival of loggerhead sea turtles (Caretta caretta) nesting in peninsular Florida: a cause for concern. Herpetol Conserv Biol 6:443-448

Scales KL, Lewis JA, Lewis JP, Castellanos D, Godley BJ, Graham RT (2011) Insights into habitat utilisation of the hawksbill turtle, Eretmochelys imbricata (Linnaeus, 1766), using acoustic telemetry. J Exp Mar Biol Ecol 407:122-129

Seaman DE, Powell RA (1996) An evaluation of the accuracy of kernel density estimators for home range analysis. Ecology 77:2075-2085

Seney EE, Landry AM Jr (2008) Movements of Kemp's ridley sea turtles nesting on the upper Texas coast: implications for management. Endang Species Res 4:73-84

Troëng S, Dutton PH, Evans D (2005) Migration of hawksbill turtles Eretmochelys imbricata from Tortuguero, Costa Rica. Ecography 28:394-402

> Van Dam RP, Diez CE (1997) Diving behavior of immature 
hawksbill turtles (Eretmochelys imbricata) in a Caribbean reef habitat. Coral Reefs 16:133-138

- Van Dam RP, Diez CE (1998a) Home range of immature hawksbill turtles (Eretmochelys imbricata (Linnaeus)) at two Caribbean islands. J Exp Mar Biol Ecol 220:15-24

Van Dam RP, Diez CE (1998b) Caribbean hawksbill turtle morphometrics. Bull Mar Sci 62:145-155

Van Dam RP, Diez CE, Balazs GH, Colón Colón LA, McMillan WO, Schroeder B (2008) Sex-specific migration patterns of hawksbill turtles breeding at Mona Island, Puerto Rico. Endang Species Res 4:85-94

- Velez-Zuazo X, Ramos WD, Van Dam RP, Diez CE, AbreuGroboiss A, McMillan WO (2008) Dispersal, recruitment and migratory behaviour in a hawksbill sea turtle aggregation. Mol Ecol 17:839-853

Vincent C, McConnell BJ, Ridoux V, Fedak MA (2002) Assessment of Argos location accuracy from satellite tags deployed on captive gray seals. Mar Mamm Sci 18: 156-166

> Voegeli FA, Smale MJ, Webber DM, Andrade Y, O'Dor RK (2001) Ultrasonic telemetry, tracking and automated monitoring technology for sharks. Environ Biol Fishes

Submitted: January 10, 2012; Accepted: April 2, 2012
60:267-281

- Wallace BP, DiMatteo AD, Hurley BJ, Finkbeiner EM and others (2010) Regional management units for marine turtles: a novel framework for prioritizing conservation and research across multiple scales. PLoS ONE 5:e15465

White GC, Garrott RA (1990) Analysis of wildlife radiotracking data. Academic Press, New York, NY

Witherington B, Kubilis P, Brost B, Meylan A (2009) Decreasing annual nest counts in a globally important loggerhead sea turtle population. Ecol Appl 19:30-54

Witt MJ, McGowan A, Blumenthal JM, Broderick AC and others (2010) Inferring vertical and horizontal movements of juvenile marine turtles from time-depth recorders. Aquat Biol 8:169-177

> Worton BJ (1987) A review of models of home range for animal movement. Ecol Modell 38:277-298

- Worton BJ (1989) Kernel methods for estimating the utilization distribution in home-range studies. Ecology 70 : 164-168

- Worton BJ (1995) Using Monte Carlo simulation to evaluate kernel-based home range estimators. J Wildl Manag 59: 794-800

Proofs received from author(s): June 9, 2012 